\title{
INVESTIGATION ON THE RELATIONSHIP BETWEEN THE CHANGE OF RIVER MOUTH SANDBAR AND RIVER DISCHARGE AND OCEAN WAVE ENERGY AT OMONO RIVER
}

\author{
*Junya Taniguchi ${ }^{1}$, Kazuya Watanabe ${ }^{2}$ and Noritoshi Saito ${ }^{3}$ \\ ${ }^{1}$ Graduate School of Engineering Science, Akita University, Japan, ${ }^{2}$ Associate Professor, Graduate School \\ of Engineering Science, Akita University, Japan, ${ }^{3}$ Technician, Graduate School of Engineering Science, \\ Akita University, Japan
}

*Corresponding Author, Received: 30 Nov. 2021, Revised: 8 Dec. 2021, Accepted: 26 Dec. 2021

\begin{abstract}
A lot of sand was deposited at river mouth of the gentle flow river and the sandbar was formed. The river mouth sandbar topography was affected by combined forces, such as river discharge, sea waves, and wave direction, etc. River mouth sandbar interrupts salt and wave intrusion and affects the navigation of cruisers and fishing vessels. A field investigation was carried out for change of a river mouth sandbar in Omono River which was located in Akita Prefecture in Japan. The topographic surveys using UAV were conducted. Then, analysis of the sandbar change process was conducted on how sandbar area and river mouth width were calculated from reconstructed topography by the SfM technique. Moreover, an investigation of a relationship between sandbar area and river mouth width and river discharge, cross-shore, and longshore direction waves was carried out. As a result, the following results were confirmed from this study. (1) Right side sandbar has the sand spit which faced the south or left side sandbar was developed very much in winter. (2) Sandbar area and river mouth width have a positive interrelation between river discharge and cross-shore waves. (3) Sandbar area has a strong negative interrelation between river mouth width.
\end{abstract}

Keywords: Omono River, Sandbar area, River mouth width, River discharge, Ocean wave, Energy flux

\section{INTRODUCTION}

A lot of sand was deposited at river mouth of the gentle flow river and the sandbar was formed [1]. Developing sandbar prevents ocean waves and salinity from intruding and affects the navigation of cruisers and fishing vessels. On the other hand, these kinds of reasons, the behavior of river mouth topographic change was required to understand for river management. There is a seasonal characteristic at the river on the Sea of Japan coast. Sandbar was grown up in winter because river discharge was decreased, and ocean wave was developed by the monsoon from the Northwest. Sandbar was decreased in spring, summer, and Autumn because river discharge was increased by snowmelt or heavy rain [2].

In previous studies, sandbar area, recovery of river mouth sandbar on Nanakita River were researched to take aerial photographs and analytical solution of one-line model [3]. Variation of sandbar on Yura River was studied to observe shape and sandbar area and conducted flume experiment and numerical simulation [4]. The reformation of sandbar at Tenjin River after a typhoon event was studied by field investigation on sandbar topography using UAV (Unmanned Aerial Vehicle) and RTK-GNSS [5].

Sandbar was grown up from both sides at the river mouth on the Omono River. So, few studies were carried out about the river mouth sandbar on the Omono River. Dynamics of sand movement between river mouth terrace and river mouth was studied using aerial photographs, sandbar shape, and submarine topography map [6]. Recovery process of sandbar after a flood was monitored using UAV and was carried out experiences [7]. However, it is necessary for understanding the change of sandbar in detail to increase the frequency of the field observation and study quantitatively the relationship between sandbar and external force which river discharge and ocean wave.

In this study, first, sandbar was reconstructed conducting UAV survey and using SfM (Structure from Motion) technique. Second, change of river mouth sandbar topography was observed and sandbar area and river mouth width were calculated. Finally, it was studied about the relationship between sandbar which change of sandbar shape, sandbar area, and river mouth width and external force which river discharge and ocean wave.

\section{STUDY AREA}

Omono River was located in Akita prefecture in Japan. Figure 1 shows the location of Omono River and investigated points of data. The size of the catchment area is $4710 \mathrm{~m}^{2}$ and the channel 


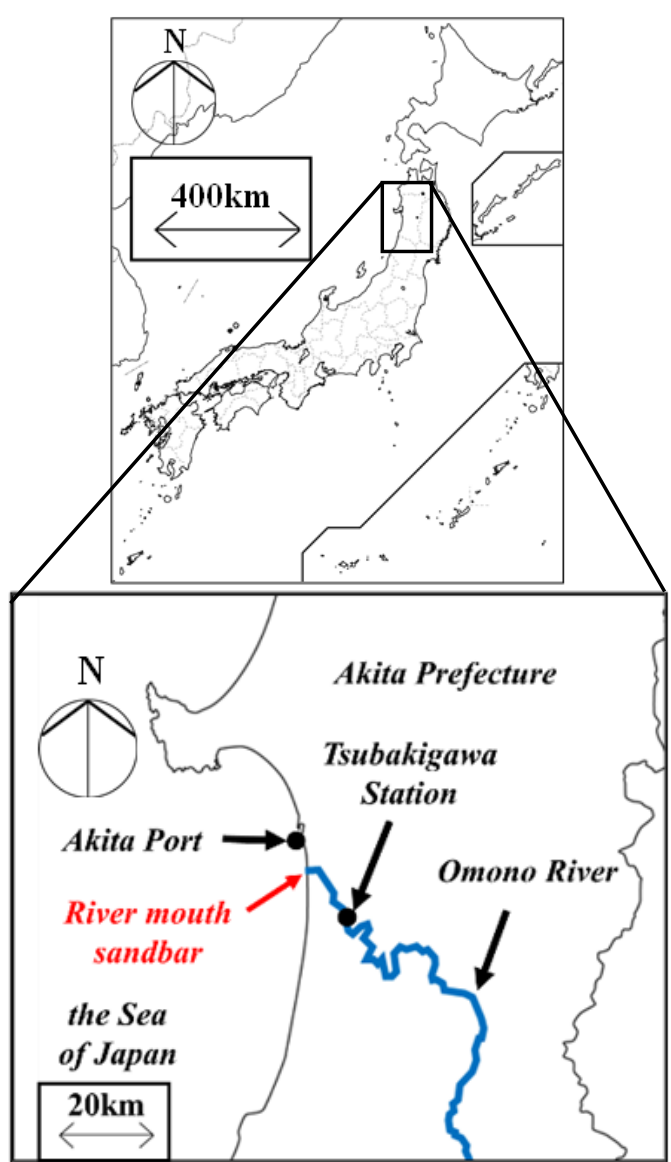

Fig. 1 Location of Omono River and investigated places of data.

extension is $133 \mathrm{~km}$. The channel bed profile in the downstream area is $1 / 4000 \sim 1 / 5000$, so Omono River is the gentle flow river. Estimated high water discharge on the river mouth is $9300 \mathrm{~m}^{3} / \mathrm{s}$. This river flows towards the Sea of Japan and there is long sandy coast on both sides of the river mouth.

River discharge, significant wave height, and wave direction were observed by Ministry of Land, Infrastructure, Transport and Tourism. River discharge was observed for every 1 hour at Tsubakigawa station which was located at the upper $13.1 \mathrm{~km}$, ocean waves data such as significant wave height $H_{1 / 3}$ and wave direction were observed for every 20 minutes at Akita Port. Anyway, waves of 0-180 degrees from the north clockwise toward sea from land because ocean waves which toward land from sea was considered [8]. Cross-shore deepwater wave energy flux is defined as

$E_{f C}=\frac{1}{16} \rho g\left(H_{1 / 3}\right)_{0}^{2} C_{g 0} \cos \theta$

and longshore deepwater wave energy flux is defined as

$E_{f L}=\frac{1}{16} \rho g\left(H_{1 / 3}\right)_{0}^{2} C_{g 0} \sin \theta$

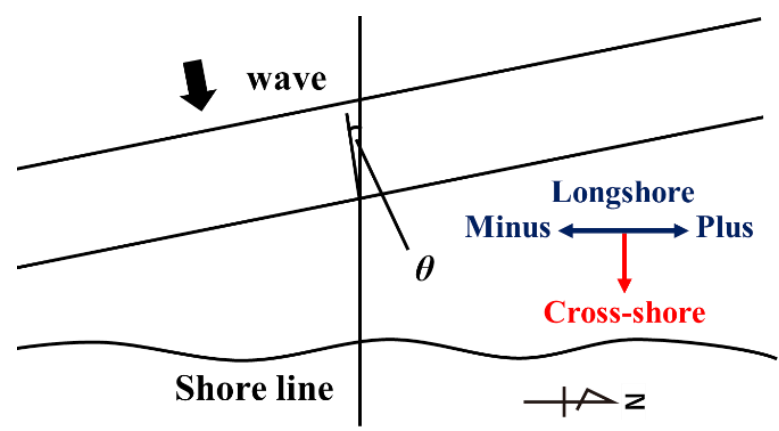

Fig. 2 The definition of energy flux.

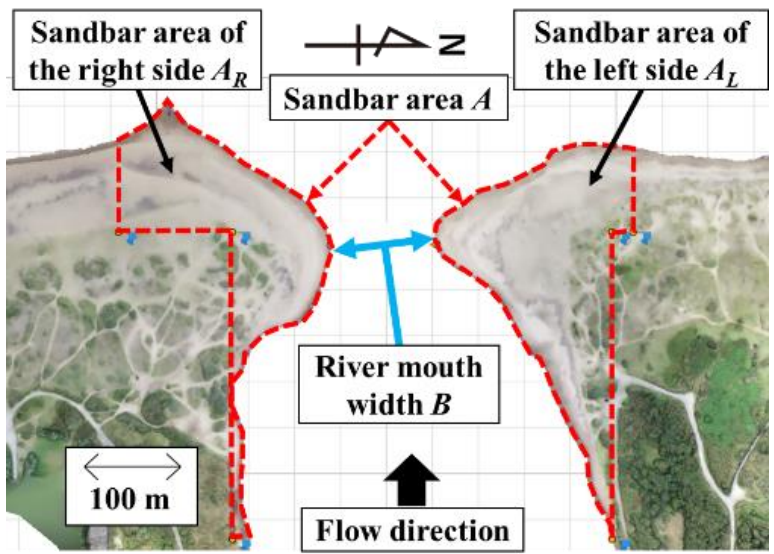

Fig. 3 The reconstructed river mouth sandbar.

in which $\rho$ is sea water density, $g$ is gravitational acceleration, $C_{g 0}$ is group velocity and $\theta$ is incident angle [9]. Figure 2 shows the definition of crossshore wave deepwater energy flux and longshore wave deepwater energy flux. Regarding longshore deep water wave energy flux, plus number means ocean waves gone to the north and minus number means ocean waves gone to the south.

\section{STUDY METHOD}

At first, UAV survey, sandbar photographs were taken to overlap $80 \%$ horizontal and vertical from ground to $150 \mathrm{~m}$ height, was carried out [10].

Next, sandbar topography was reconstructed using SfM technique from taken aerial photographs. Figure 3 shows the reconstructed sandbar.

Then, sandbar area $A$, sandbar area of the right side $A_{R}$, sandbar area of the left side $A_{L}$ and river mouth width $B$ were calculated from the reconstructed sandbar. Sandbar area was defined as the part which sandbar was changed greatly in the river mouth. River mouth width was defined as the part which the distance between both sides of the sandbar was shortest. Also, shoreline was not modified considering sea level because tidal range is small on seashore on the sea of Japan [11]. 


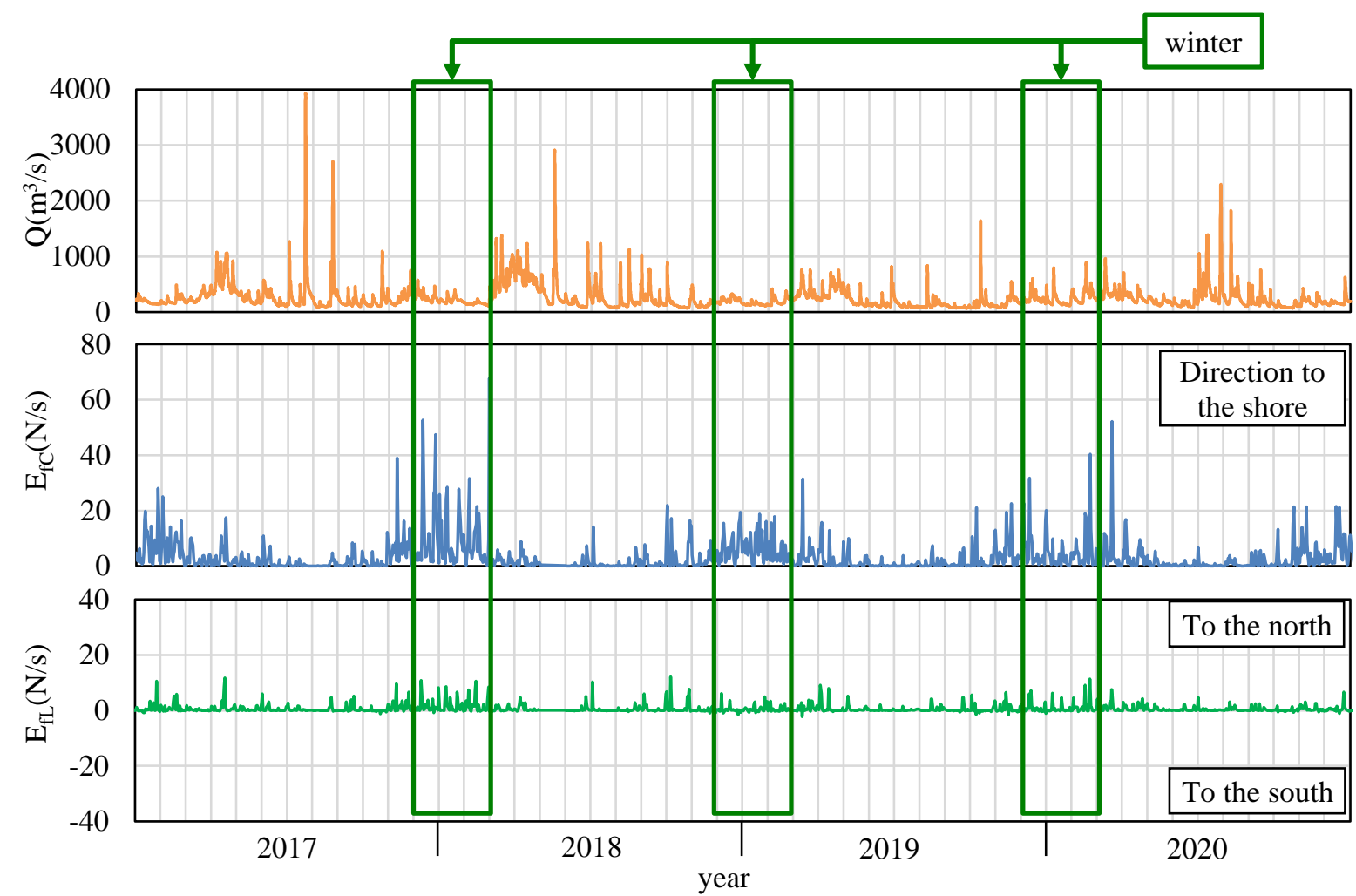

Fig. 4 River discharge, cross-shore deepwater wave energy flux and longshore deepwater wave energy flux.

Finally, calculated sandbar data were compared with river discharge and deepwater wave energy flux to examine the relationship between sandbar and external forces.

\section{RIVER DISCHARGE, CROSS-SHORE AND LONGSHORE DEEPWATER WAVE ENERGY FLUX}

Figure 4 shows river discharge, cross-shore deepwater wave energy flux and longshore deepwater wave energy flux from 2017 to 2020. River discharge was used data for every 1 hour. Energy flux data were averaged for 24 hours.

River discharge was decreased to $100-500 \mathrm{~m}^{3} / \mathrm{s}$ in winter every year. After that, it was increased to $700-1500 \mathrm{~m}^{3} / \mathrm{s}$ by snowmelt in spring and greatly increased by heavy rain in summer and autumn.

Cross-shore energy flux was excelled in comparison with longshore deepwater wave energy flux. Cross-shore energy flux was gradually decreased from spring to summer and was weakest in summer. Then, It was gradually increased from autumn to winter and was strongest in winter. Longshore energy flux was changed like crossshore energy flux. Also, it was gone to the north.

\section{CHANGE OF THE SANDBAR}

Figure 5 shows change of the sandbar shape from 2017 to 2020 . Sand spit was formed toward the south from the right side sandbar and river channel was curved to the southwest in winter. River discharge was decreased most and energy flux was strongest in winter as indicated in Figure 4. Therefore, it was considered that, first, a lot of sand was carried away offshore. Second, it was transported to river mouth by ocean waves. Third, ocean waves and river flow were balanced in winter. Finally, sand spit was formed because a lot of sand was deposited at the offing of the river mouth.

River discharge was increased caused by snowmelt and energy flux was decreased. Hence, sand spit was reduced or disappeared, and river mouth width was extended in spring.

River mouth width was extended more because river discharge was sometimes increased greatly by heavy rain in summer and autumn. Shoreline was repeatedly advanced and went back on both sides. To focus on winter, it was found out that shoreline was very different every year. Thus, it was not able to find the relationship between shoreline and external forces.

\section{PROJECTION OF THE SANDBAR}

Projection to offshore was formed from both sandbar when sand was deposited at the sandbar [6]. A very shallow half-circle river mouth terrace exists from the projection. Ocean waves and salinity intrusion was affected by the terrace. Moreover, it was important to understand recovery of sand. 


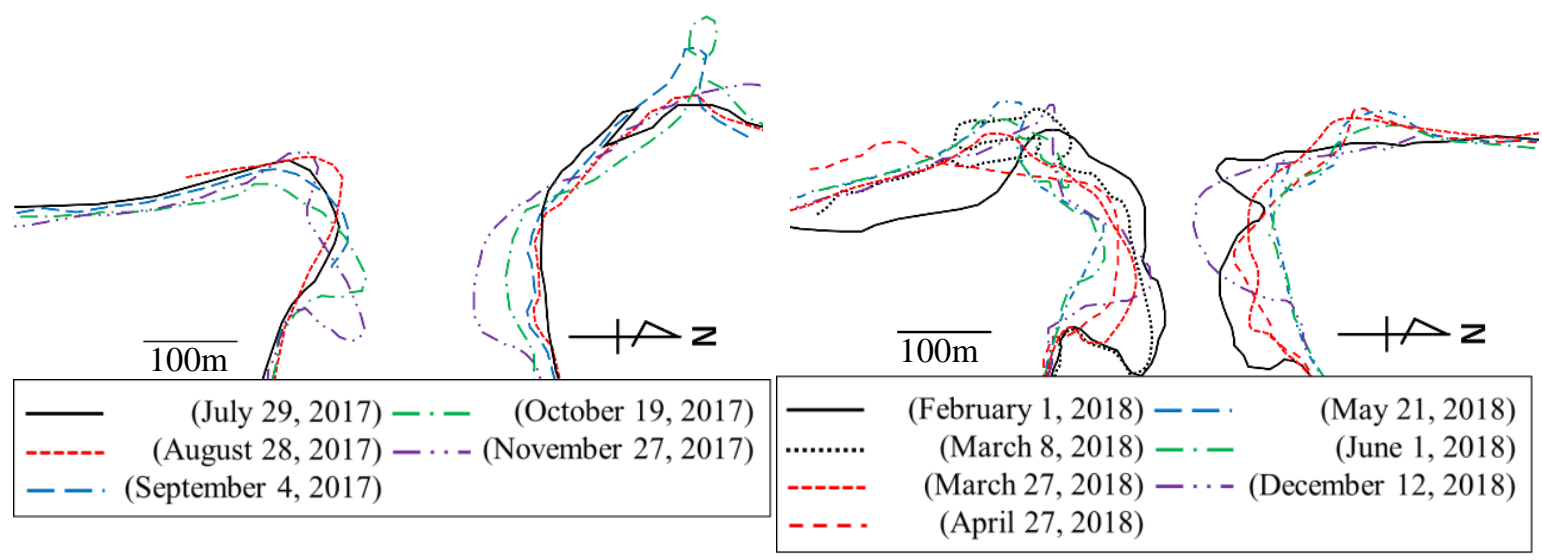

(a) 2017 year

(b) 2018 year

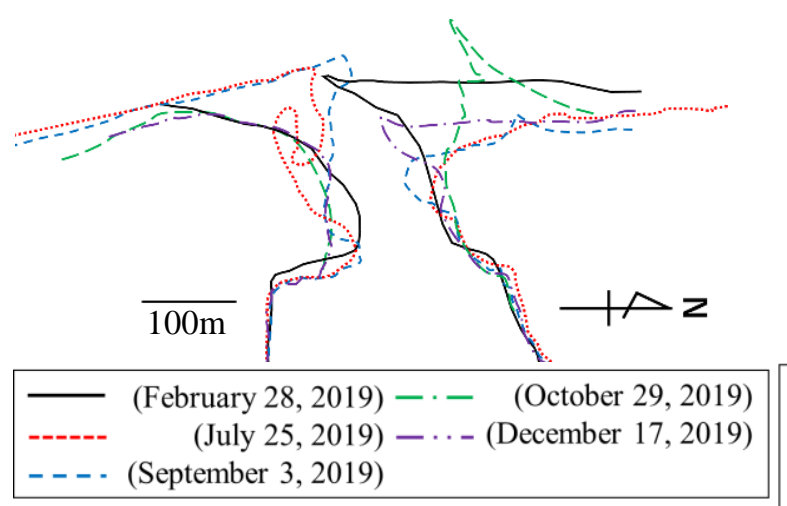

(c) 2019 year

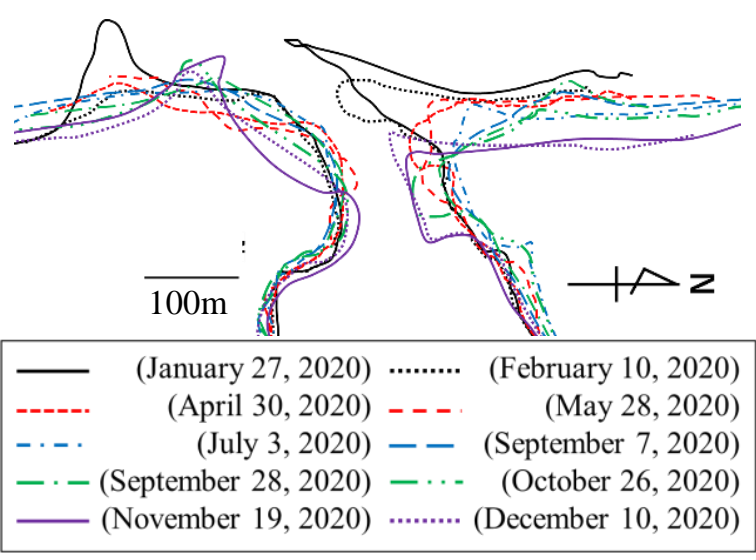

(d) 2020 year

Fig. 5 Change of the sandbar shape from 2017 to 2020 year.

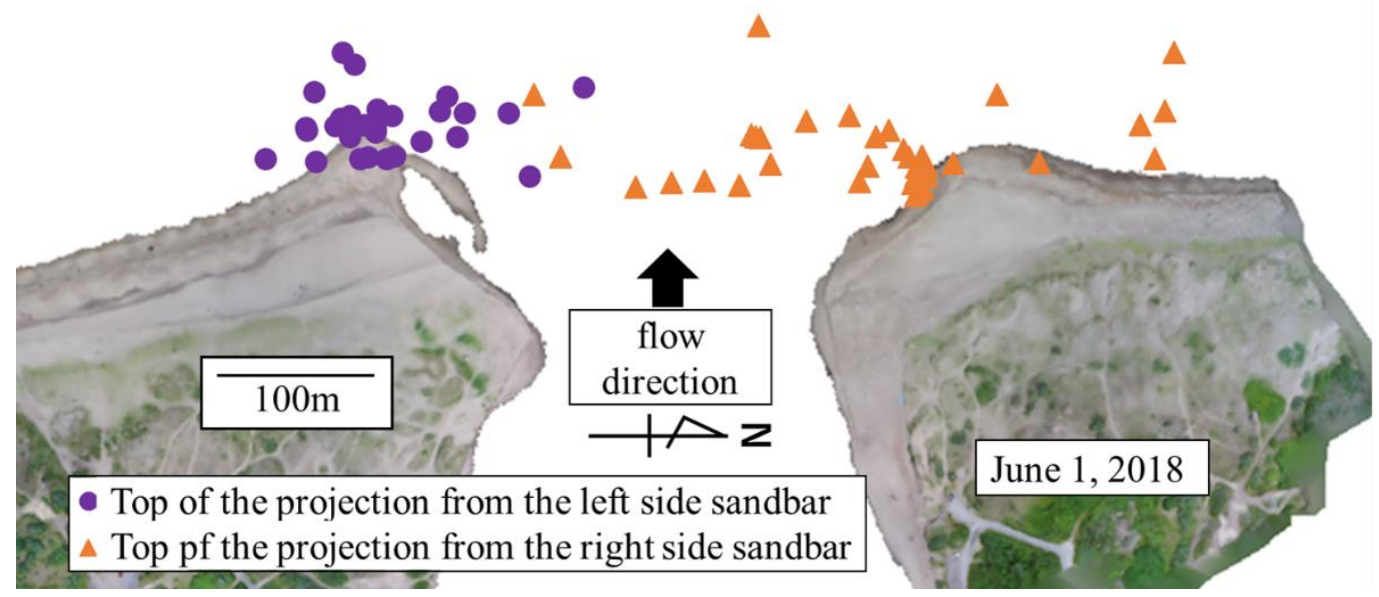

Fig. 6 Change of the sandbar shape from 2017 to 2020 year.

Therefore, study on the place of the projection was carried out. Figure 6 shows top of the projection and the reconstructed sandbar on May 25, 2018 by SfM technique. Projections of the right side sandbar were formed widely regardless of season. Particularly, it was formed near the left side because of sand spit for the south from the right side. On the other hand, projections from the left side were formed at a similar place. It was considered that sand was controlled by the artificial reef which was constructed offshore of the left side [12].

\section{CHANGE OF SANDBAR AREA AND RIVER MOUTH WIDTH}

Figure 7 shows change of the river mouth 


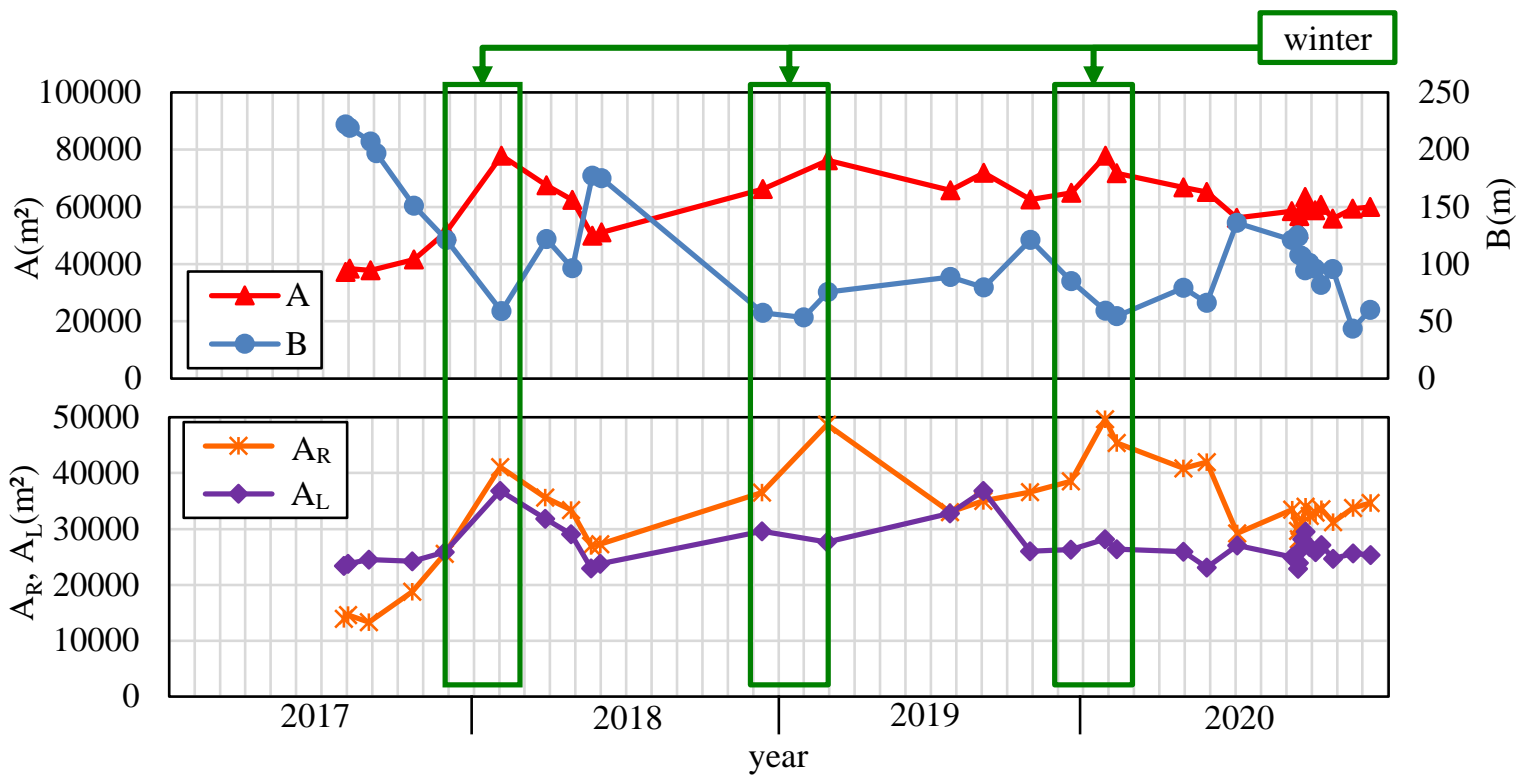

Fig. 7 Change of sandbar area, river mouth width, sandbar area of the right side, and the left side.

sandbar area, river mouth width, sandbar area of the right side and sandbar area of the left side from 2017 to 2020 year. Sandbar area was the largest, approximately $80,000 \mathrm{~m}^{2}$, in winter. It was decreased gradually from spring to summer or autumn and was smallest in summer or autumn. Therefore, it was considered that sandbar area was decreased because sand was drained from sandbar by strong river flow caused by snowmelt in spring and heavy rain and typhoon in summer and autumn. Then, it was gradually increased from autumn to winter because a lot of sand was carried and deposited at river mouth sandbar by strong ocean waves. It was found out that sandbar area change was similar to sandbar topographic change. Thus, it was proved that the topographic change of sandbar was able to evaluate quantitatively to monitor using UAV and SfM technique.

River mouth width was got narrow most, about $50 \mathrm{~m}$, in winter. It was extended from spring to summer or autumn and was widest in summer or autumn. Furthermore, it was gradually got narrow from autumn to winter. These results show that sand was drained from sandbar caused by river flow in spring, summer and autumn. Moreover, river mouth width became narrow due to sand was deposited at river mouth by strong ocean waves. According to results, it was found that river mouth width was changed like river mouth of the other rivers on the Sea of Japan [13], [14].

Sandbar area of the right side was largest in winter and was smallest in summer or autumn. Thus, it was changed like the whole of the sandbar area. On the other hand, the left side was not able to confirm seasonal characteristics and was not similar to the whole of the sandbar area. Additionally, the right side was changed more than the left side. From

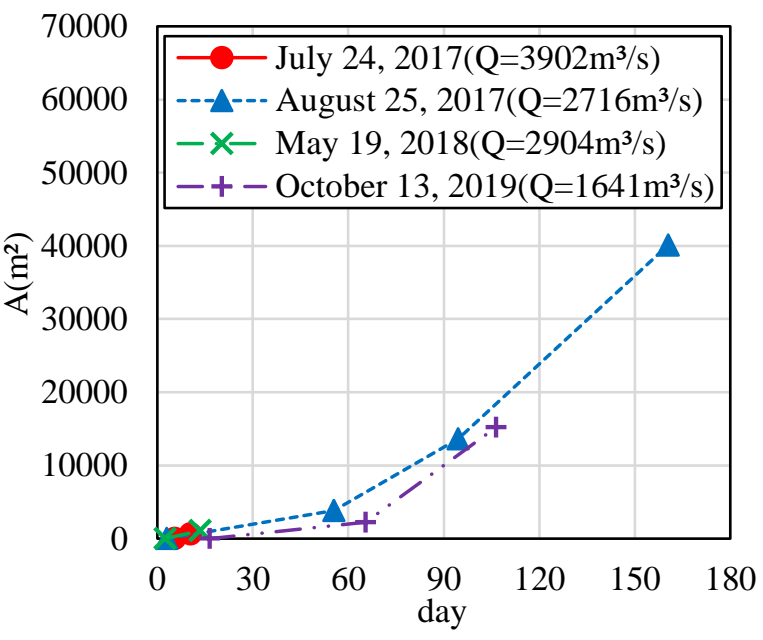

Fig. 8 Change of sandbar area after the flood.

these results, the right side sandbar is important for the management of the river mouth sandbar.

\section{RECOVERY OF THE SANDBAR}

Recovery of the sandbar after the flood was examined to study change of the sandbar area. When river discharge was exceeded $1,500 \mathrm{~m}^{3} / \mathrm{s}$ as the flood and sandbar area change after the flood was studied. Figure 8 shows change of the sandbar area after the flood. Anyway, the days of the flood that happened were regarded as 0 days. And sandbar area on observation day just after the flood was regarded as $0 \mathrm{~m}^{3} / \mathrm{s}$. The day of the flood and maximum river discharge in the flood were shown in a legend in the figure. Sandbar area was gently increased until about 60 days after. However, it was drastically increased after about 90 days.

Figure 9 shows change of the right side sandbar 


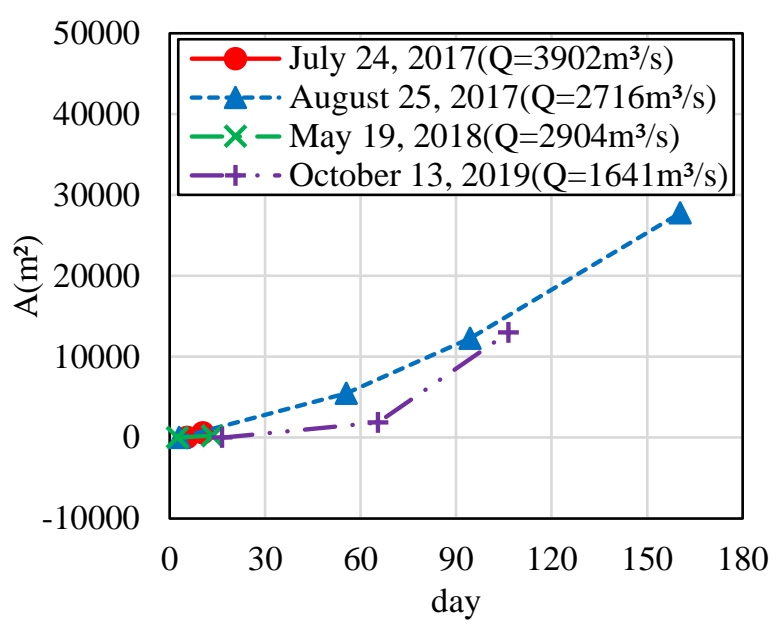

Fig. 9 Change of the right side sandbar area after the flood.

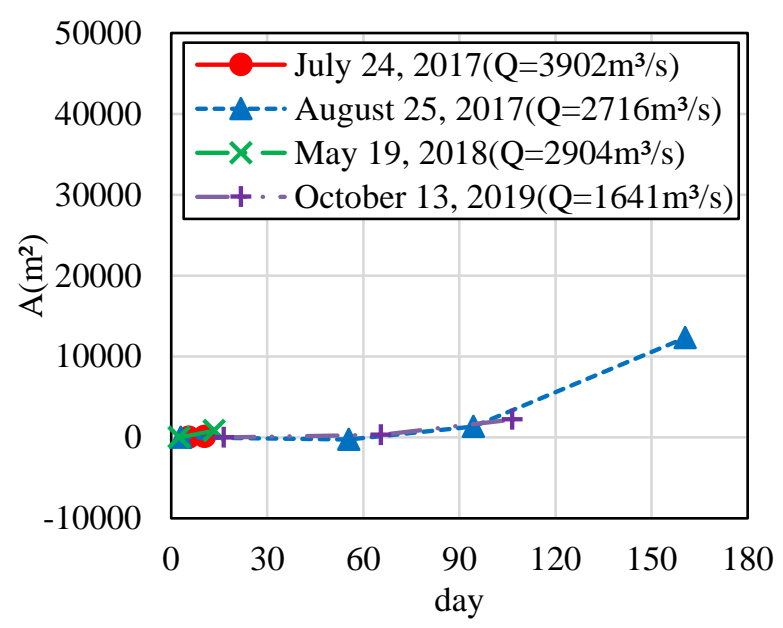

Fig. 10 Change of the left side sandbar area after the flood.

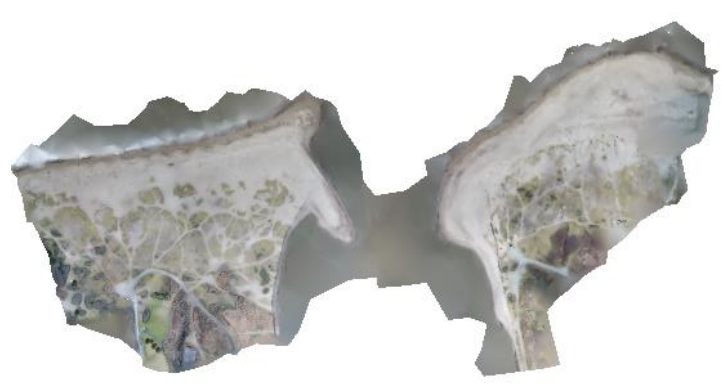

Fig. 11 The reconstructed sandbar topography on November 27, 2017.

area after the flood and figure 10 shows change of the left side sandbar. Using data were similar to figure 8 . The right side sandbar area was increased gently until about 60 days after and increased drastically after about 90 days after. On the other hand, the left side sandbar area was not changed until about 90 days after and increased after that. From these results, a lot of was sand transported from offshore was controlled by artificial reef
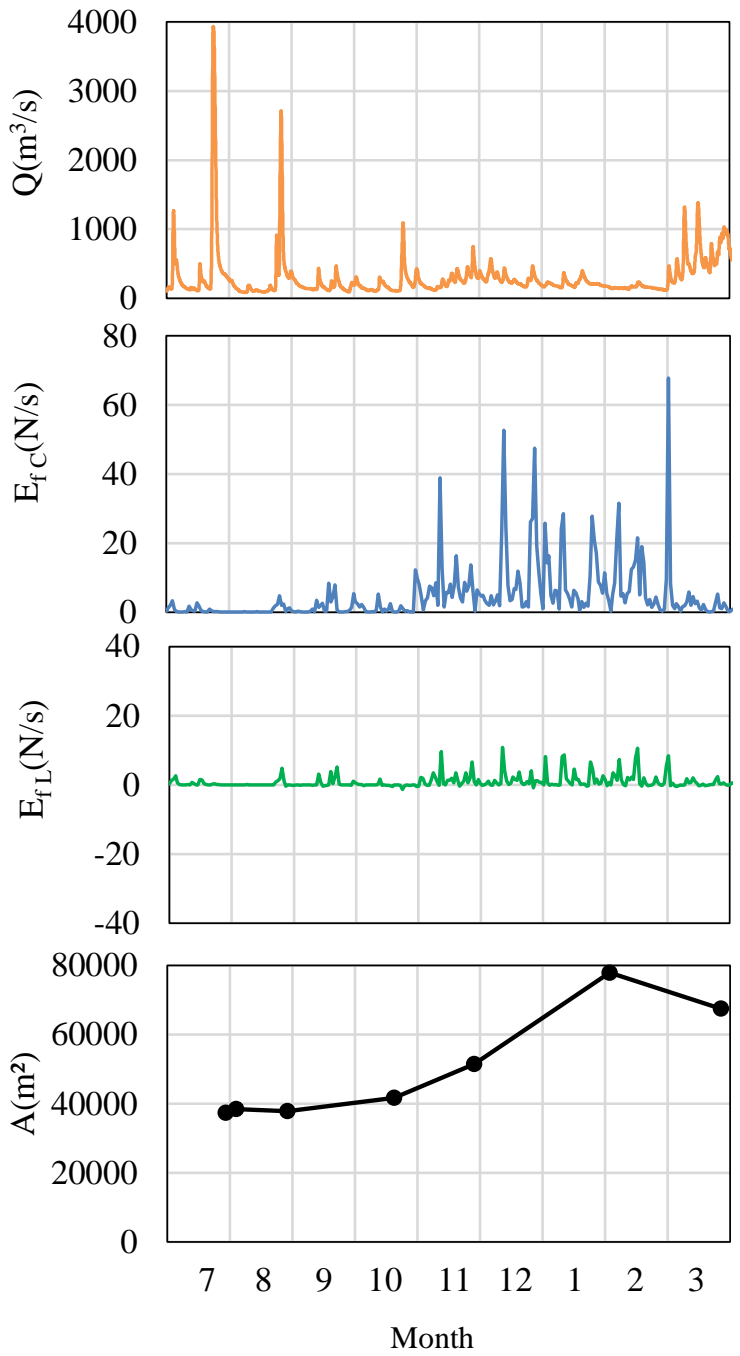

Fig. 12 River discharge, energy flux and change of sandbar area from July, 2017 to March, 2018.

constructed offshore of left side sandbar. Figure 11 shows the topography on November 272017. Vegetation grows up for the center of the channel from the left side. However, it was not grown up from the right side. Additionally, the right side sandbar was developed in Figure 5 (a). Therefore, it was considered that the development of sandbar was affected by vegetation.

Change of sandbar area after the flood on July 24, 2017 was focused to study the relationship between recovery of the sandbar and external forces in detail. Figure 12 shows change of sandbar, river discharge, cross-shore deepwater wave energy flux and longshore deepwater wave energy flux from July, 2017 to March, 2018. At first, sandbar area was about $40,000 \mathrm{~m}^{2}$ just after the flood on July 24 and sandbar did not exist in river channel in Figure 5 (a). Sandbar area was increased slightly early in August despite energy flux was very weak. Anyway, river discharge was decreased until the early of August. Thus, it was considered that sandbar was seemed to be small due to water level was fall that 

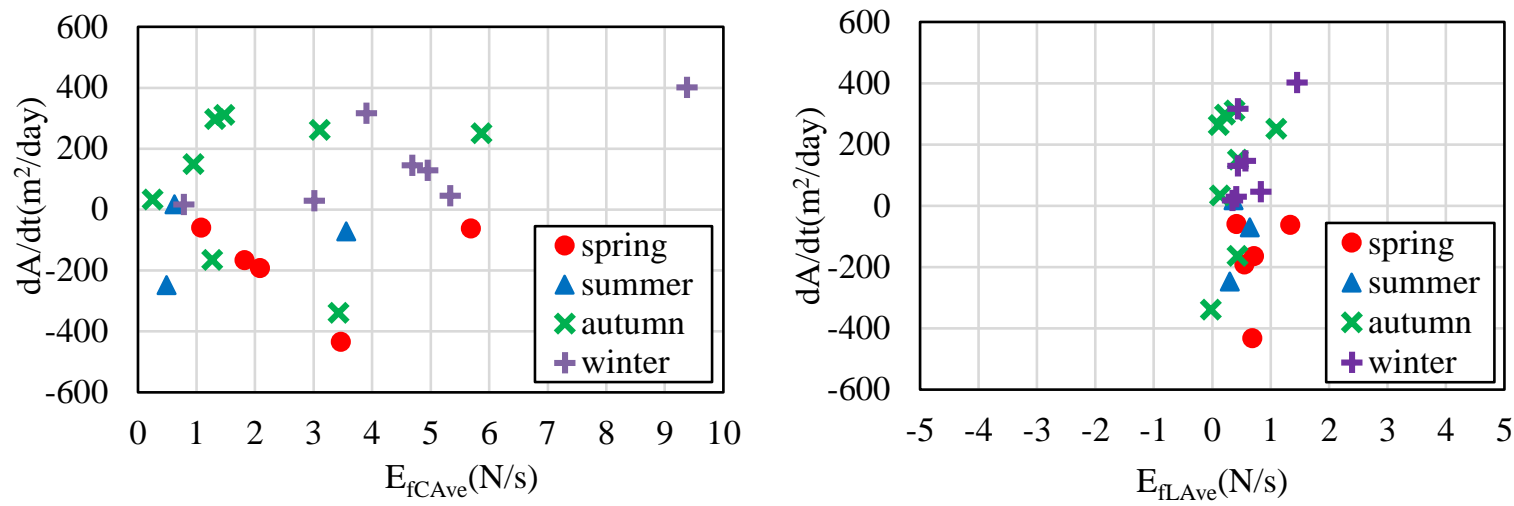

Fig. 13 The relationship between sandbar area and energy flux.
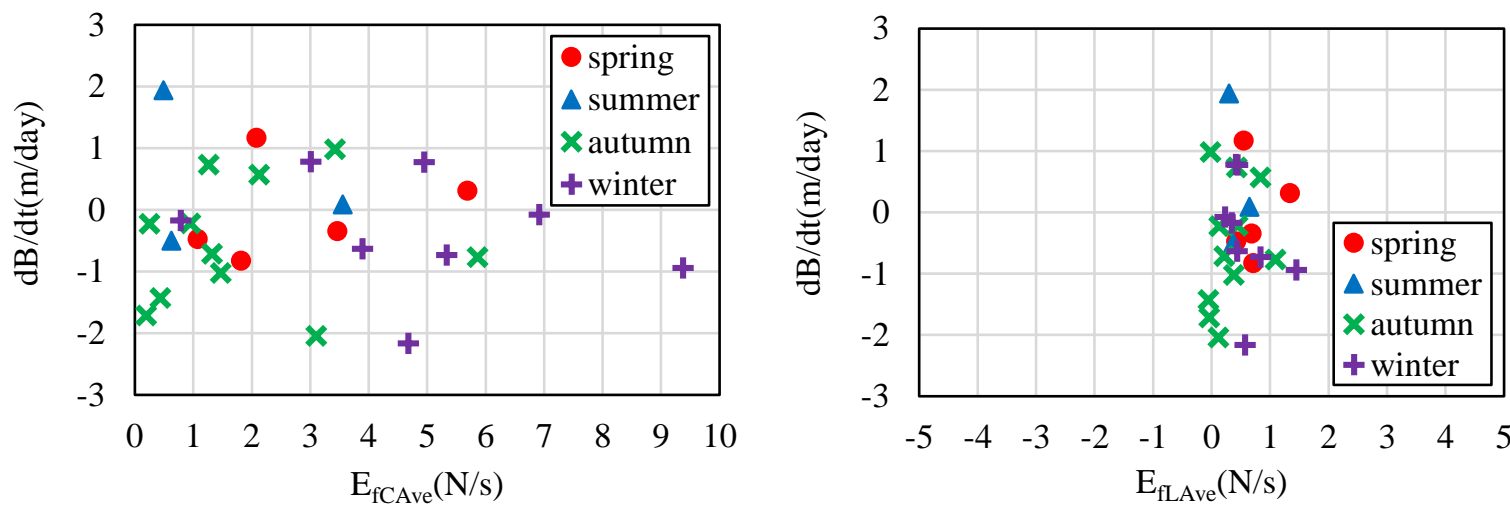

Fig. 14 The relationship between river mouth width and energy flux.

is river discharge was decreased.

River discharge had never been very increased after September and sandbar area was gradually increased. Sandbar was developed to the center of the channel from both sides and the projection was formed to offshore from the right side.

November to February Sandbar area was increased sharply from and was arrived at two times of July and August. Sandbar was developed to the center of the channel from both sides and the projection to the south was formed from the right side. Energy flux was very strong from November to February. Therefore, it was confirmed that sandbar was developed drastically due to a lot of sand that had been carried away offshore was transported and deposited at the river mouth by strong ocean waves.

\section{THE RELATIONSHIP BETWEEN CHANGE OF SANDBAR DATA AND ENERGY FLUX}

Change of sandbar area in a day from $x$ day to $y$ day was defined as $d A / d t$ and variation of river mouth width in a day from $x$ day to $y$ day was defined as $d B / d t$. Equation (3) is change of sandbar area per day. $\frac{d A}{d t}=\frac{A_{y}-A_{x}}{y-x}$

Equation (4) is river mouth width variation in a day.

$\frac{d B}{d t}=\frac{B_{y}-B_{x}}{y-x}$

Mean of cross-shore deepwater wave energy flux from $x$ day to $y$ day that $E_{f C A v e}$ and mean of longshore deepwater wave energy flux from $x$ day to $y$ day that $E_{f L A v e}$ were calculated. Furthermore, the relationship between change of sandbar area and energy flux, and the relationship between change of river mouth width and energy flux were studied. Figure 13 shows the relationship between change of sandbar area and energy flux. Figure 14 shows the relationship between change of river mouth width and energy flux. Also, data within 6 days were removed due to water level was risen and fallen intensely and sandbar was affected strongly.

It was found that sandbar area was changed from -500 to $+400 \mathrm{~m}^{2}$ in a day and river mouth width was changed from -2 to $+2 \mathrm{~m}$ in a day. On the other hand, it was not discovered that the relationship between sandbar data and energy flux.

Being plus in winter and minus in spring and summer, sandbar area was confirmed that was 
increased in winter and decreased in spring and summer.

Change of river mouth width was positive in spring, summer, and winter. However, it was negative regardless of season. According to these results, river mouth width was extended by strong river flow in spring, summer, and autumn, just after that, sand was deposited on river mouth sandbar.

\section{CONCLUSIONS}

It would be concluded as follows.

1) Sandbar of Omono River was reduced due to strong river flow by snowmelt in spring and heavy rain in summer and autumn. Then, it was extended due to sand was transported and deposited by ocean waves from autumn to winter like other rivers on the Sea of Japan.

2) Sandbar area was largest in winter and was smallest in summer or autumn. However, river mouth width was got narrow in winter and was widest in summer or autumn.

3) Sandbar area was changed from -500 to +400 $\mathrm{m}^{2}$ in a day. River mouth width was changed from -2 to $+2 \mathrm{~m}$ in a day.

\section{ACKNOWLEDGEMENTS}

The author would like to thank Ministry of Land, Infrastructure, Transport and Tourism for their contributions to this study.

\section{REFERENCES}

[1] Shimatani H., Sasamoto M., Kasai S., Ohba K., Fuse Y. and Sakai S., River Mouth Fluctuation of Yoneshiro River, Proceeding of Coastal Engineering, JSCE, Vol. 44, 1997, pp. 571-575. (in Japanese)

[2] Nishikawa K., Sasaki M., Maekawa K., Uda T. and Kunimatsu H., River Mouth Topography Changes at the Mogami River, Proceeding of Coastal Engineering, JSCE, Vol. 37, 1990, pp. 374-378. (in Japanese)

[3] Hoang C.V., Tanaka H. and Mitobe Y., Morphological Evolution of Beach Adjacent to the River Mouth After the 2011 Tsunami, Proceeding of the $36^{\text {th }}$ IAHR World Congress, 2015, pp. 4379-4385.

[4] Miwa H., Kanda K., Ochi T. and Kawaguchi H., Dynamic state of river-mouth bar in the Yuragawa River and its control under flood flow conditions, Proceedings of the 13rd International Symposium on River Sedimentation, 2016, pp. 710-718.

[5] Katayama T., Kuroiwa M., Kajikawa Y. and Kurasige H., Field Investigation for
Morphodynamic of River Mouth Bar Using UAV and RTK-GNSS, Proceedings of the $10^{\text {th }}$ International Conference on Asian and Pacific Coasts, Vol. 74, No. 2, 2018, pp. 793-798.

[6] Uda T. and Matsuda H., Relation between the Formation and Disappearance of a River Mouth Bar and a River Mouth terrace in the Omono River, Proceedings of Coastal Engineering, JSCE, Vol. 42, 1995, pp. 566-570. (in Japanese)

[7] Noguchi, K. and Watanabe K., Study on recovery process of river-mouth sandbar using in Omono river, Proceedings of 8th International Conference on Fluid Mechanics, S01H00-33(USB Memory), 2018.

[8] Matsutomi H. and Fujita M., Verification of Correspondence of Long-term Trend of Shoreline Position and Wind Wave Height Changes on the Akita Southern Coast, Journal of Japan Society of Civil Engineer, Ser. B2 (Coastal Engineering), Vol. 70, No. 2, 2014, pp. 731-735. (in Japanese)

[9] Suzuki T. and Kuriyama Y., characteristics of Long-term Shoreline Change and the Effects of the Offshore Wave, the Energy Flux and Longshore Current Velocity on the Shoreline Change Rate, Report of the Port and Airport Research Institute, Vol. 47, No. 3, 2008, pp. 330.

[10] Taniguchi J., Watanabe K. and Saito N., Study on the Behavior of Sandbar in a River Channel at the Babamegawa River, International Journal of GEOMATE, Vol. 20, issue 78, 2021, pp. 115120.

[11] Matsutomi H. and Kondo Y., Kimura T. and Tanaka H. Long- and Short- term Trends of Shoreline Position Change near the New Mouth of the Omono, Proceedings of Coastal Engineering, JSCE, Vol. 55, 2008, pp. 636-640 (in Japanese)

[12] Ministry of Land, Infrastructure, Transport and Tourism, Omono River Channel Improvement Measures, 2016, 161p. (in Japanese)

[13] Maekawa K. and Kon A., On Change in the Topography at the Mouth of the Aka River, Bulletin of the Yamagata University. Agriculture science, Vol. 11, No. 4, 1993, pp. 891-898.(in Japanese)

[14] Ochi T., Kanda H., Miwa H., and Nakamura F., Research on the Dynamic State of River-Mouth Bar under Flood Conditions in the Yuragawa River, E-proceedings of the $36^{\text {th }}$ IAHR World Congress, 2015, pp. 2428-2439.

Copyright (C) Int. J. of GEOMATE. All rights reserved, including the making of copies unless permission is obtained from the copyright proprietors. 